\title{
Pro-Poor Modes of Technical Integration into the Global Economy
}

\author{
Jeffrey James
}

\begin{abstract}
Recent evidence indicates that globalization based on technical advances in information technology is creating a dualistic situation in the world economy, whereby the benefits tend to accrue to a narrow group of relatively affluent countries, while the majority lag behind. The purpose of this article is to suggest a framework within which to assess an alternative, pro-poor form of technical integration into the global economy - in other words, a form of globalization that benefits the poor as well as the rich. The article focuses particularly on the role that can be played by NGOs, aid donors and national governments in this endeavour.
\end{abstract}

\section{INTRODUCTION}

According to the most recent Human Development Report, globalization based on technological advances such as the Internet, mobile phones and fax machines is creating 'parallel worlds' - one which is using these technological advances for rapid growth and another which is falling ever further behind:

Those with income, education and - literally - connections have cheap and instantaneous access to information. The rest are left with uncertain, slow and costly access. When people in these two worlds live and compete side by side, the advantage of being connected will overpower the marginal and impoverished, cutting off their voices and concerns from the global conversation. (UNDP, 1999: 6)

Left to itself, the market mechanism will not narrow the gap between these two worlds. On the contrary, the gap will tend to widen over time in the cumulative fashion originally envisaged by Gunnar Myrdal (1957). What is needed, therefore, as the same Human Development Report rightly emphasizes, is a set of countervailing policies that will enable a much larger share of the world's population to be integrated with and enjoy the benefits of globalization. ${ }^{1}$ However, the identification of such a policy agenda needs

1. For the purpose of this article, globalization is defined in terms of increasing ratios of foreign trade and investment to total world output (following the World Bank, 1996).

Development and Change Vol. 31 (2000), 765-783. (C) Institute of Social Studies 2000. Published by Blackwell Publishers, 108 Cowley Road, Oxford OX4 1JF, UK. 
to be undertaken systematically; it should, in particular, address the following three issues:

(1) Who are the poor? (for instance, in terms of location, occupation and gender);

(2) By what modes are individuals and firms technologically integrated into the global economy? (for example, as users of communication technologies or exporters of electronic components);

(3) How can the poor, as identified under (1) above, be more intensively integrated into and benefit from the global economy by means of the mechanisms described under (2) above?

The bulk of this article will proceed along these lines, focusing on each of these three issues in turn, beginning with the nature of mass poverty. First, however, it is important to define the scope and limits of this rather ambitious project. In the first place, I shall deal only with the technological dimension of increased trade and investment flows in the global economy. The technological effects that are considered, moreover, reflect only the direct, as opposed to the indirect (or multiplier) effect on the poor, which means that in some cases the pro-poor impact of technological advance will be underestimated. Finally, it bears emphasizing that the goal of this article is not so much to forecast the extent to which information technology will favourably affect the poor, as to indicate the mechanisms through which such an outcome can best be promoted and to provide examples of where this has actually occurred.

\section{THE NATURE OF GLOBAL POVERTY}

The structure of poverty is not the same for all developing countries. One can readily point to some fairly major variations in the poverty profile of different countries. In some cases, for example, it is the self-employed that account for much of the problem, while in other cases this category is a relatively unimportant component of national poverty. ${ }^{2}$ In some cases, it is the unemployed (and underemployed) that constitute a large proportion of those living below the poverty line, while in other cases poverty is much less closely connected to these particular groups.

In spite of these differences, however, some generalizations about the nature of poverty in developing countries can be made. The first is that most of those described as living below a certain poverty line reside in rural rather than urban areas. This observation has long been emphasized in the

2. See Griffin and James (1981) for an extended discussion on the heterogeneity of poverty in developing countries. 
literature, perhaps most forcefully by Lipton in the 1970s, but it remains true for many developing countries even at the turn of the century. This is partly because the majority of the population (approximately 60 per cent) in low and middle-income developing countries still live in rural rather than urban areas. But it is also due to the fact that the incidence of poverty often tends to be markedly higher among the former rather than the latter group of people. In Brazil, for example, the percentage of the population below the poverty line is approximately 33 in rural areas as opposed to a figure of only 13 in urban locations. In Colombia, the differential is even greater with the incidence of rural poverty exceeding the corresponding urban percentage by a factor of four (UNDP, 1999).

The second generalization has to do with the crucial role played by education and labour skills in determining income inequality and poverty in developing countries. According to the World Bank, for example:

Income inequality across workers is strongly associated with inequality of education and skills. Educational attainment is the single most important predictor of individual labor incomes. Combined with other human capital variables such as experience and occupation, skills account for one-third to one-half of the variation in earnings observed across individuals within countries. (World Bank, 1995: 41)

For some developing countries, estimates show that the poor (defined as the lowest per-capita income quintile of the population) receive little or no schooling. In Guatemala, for example, this income quintile receives, on average, only one year of schooling. In Brazil, a country where the distribution of income is notoriously unequal, the lowest quintile of the population receives on average little more than two years of schooling (World Bank, 1995).

Among the unskilled and uneducated, moreover, it is fair to say that there is a higher proportion of women than men in developing countries as a whole. According to the most recent edition of the Human Development Report (UNDP, 1999), the female adult literacy rate is less than 80 per cent that of males across all developing countries and only 65 per cent in the least developed countries.

\section{MODES OF TECHNOLOGICAL INTEGRATION INTO THE GLOBAL ECONOMY}

Since we have defined globalization in terms of foreign trade and investment flows, it is in relation to these same two variables that the integrative role played by information technology needs to be described. Let us, therefore, turn first to the various ways in which this technology acts as a mode of global trade integration. ${ }^{3}$

3. This discussion is based on James (1998 and 1999). 


\section{Information Technology, Trade and Globalization}

'Communications technology' according to the most recent Human Development Report (UNDP, 1999: 57), 'sets this era of globalization apart from any other. The Internet, mobile phones and satellite networks have shrunk space and time. Bringing together computers and communications unleashed an unprecedented explosion of ways to communicate'. By facilitating the cost and speed with which buyers and sellers in different countries can communicate with one another, these more numerous, cheaper and faster modes of communication undoubtedly raise the level of international trade above what it would otherwise be. Generally speaking, one may say that communications technologies reduce information imperfections of various kinds and hence move the international trading system closer to the competitive model.

Participation in the global trading system also depends on the role played by other forms of information technology in particular branches of industrial production. For, in common with other differences in production function, differences in the use of information technologies such as computer-aided design (CAD), numerically controlled machine tools (NCMTs) and robots shape the patterns of comparative advantage - and hence trade - between countries. Some countries will exploit the competitive advantages afforded by the adoption of those particular technologies, while other countries that continue to trade on the basis of older vintages of technology, will tend to lag behind.

\section{Information Technology, Multinationals and Globalization}

Information technology has not only contributed to the increasing flows of goods and services between countries in the ways described above, but it has also brought about a fundamental change in the behaviour of multinational corporations. Most notably:

Progress in information and communication technologies has not only made it possible for firms to process and communicate vastly more information at reduced costs, but to manage, day-to-day, far-flung and widely dispersed production and service networks. Moreover, advances in combining information and telecommunication technologies have increased the transportability of many information-based services, enabling them to be traded across distances without necessarily being embodied in people or goods. (UNCTAD, 1996: 95-6)

Thus apart from inducing the multinational corporation to disperse more widely the location of its activities — including expenditures on research and development (R\&D) - information technology also permits 'substantial cost-savings in the coordination and monitoring costs associated with interfirm networks' (Dunning and Narula, 1996: 9). Associated with this is a growing and well-documented tendency for multinational firms to engage in strategic alliances of various kinds, partly, but not exclusively, in the area of information technology itself (Freeman and Hagedoorn, 1995). 


\section{Information Technology and Pro-Rich Patterns of Globalization}

Table 1 contains a summary of the mechanisms that have just been described and provides an indication of the type of information technology with which each such mechanism is likely to be associated. In the majority of cases, the gainers tend to be drawn heavily from the relatively affluent developing countries, especially the so-called first-tier NICs (Hong Kong, Singapore, Taiwan and Korea). It is in these countries, for example, that industrial technologies such as CAD and NCMTs have been most widely adopted and it is these same countries that have best been able to exploit the vast export opportunities afforded by products such as semiconductors, computers and telecommunications equipment. Within developing countries, moreover, the benefits from the information technology revolution have accrued mainly to urban rather than rural areas, large-scale rather than small-scale firms, skilled rather than unskilled workers and males rather than females. ${ }^{4}$ In some cases, the problem is not merely that technically-induced globalization leaves the poor relatively worse-off (that is, that although they do not gain, the poor are not made worse-off in an absolute sense). The problem is rather that the poor do become absolute losers when, for example, the introduction of $\mathrm{CAD} / \mathrm{CAM}$ machines increases employment among skilled workers but replaces traditional designers and handloom weavers.

This tendency for information technologies to exacerbate existing inequalities between as well as within developing countries, has its roots in the fact that innovations in general and information technologies in particular are designed for developed rather than developing countries. It is the former rather than the latter countries that usually provide an environment conducive to the application of information technologies - an environment that includes, among other things, an advanced (telecommunications) infrastructure, a skilled labour force, a high level of capital per unit of labour, and consumers with relatively high average income levels (although it is true that some products become cheaper as a result of information technology and are thus more accessible to the poor).

The point that needs to be emphasized here, however, is not simply that countries with these features (including some of the more advanced developing countries) are more likely to benefit from information technologies than countries whose technological systems cannot be thus characterized. What also needs to be recognized is that whatever initial advantages a country possesses in this respect, tend, in a market-based global economy, to accumulate rather than diminish over time, as envisaged by Myrdal's (1957) notion of cumulative causation. We have already referred, for example, to the fact that information and communication technologies allow multinational

4. For a discussion of the inegalitarian impact of information technologies within most developing countries, see James (1999). 
Table 1. Trade and Foreign-investment-induced Mechanisms of Technological Influence on Globalization

\begin{tabular}{|c|c|}
\hline Form of Information Technology & Mechanism of Influence \\
\hline $\begin{array}{l}\text { Communication technologies (e.g. mobile } \\
\text { phones, fax machines, e-mail) }\end{array}$ & $\begin{array}{l}\text { Promotes trade by reducing information } \\
\text { imperfections and expediting the flow of } \\
\text { information }\end{array}$ \\
\hline Industrial technologies (e.g. CAD, NCMTs) & $\begin{array}{l}\text { Adoption enhances competitive advantage } \\
\text { of adopting firms and countries at expense } \\
\text { of non-adopters }\end{array}$ \\
\hline $\begin{array}{l}\text { Electronics (e.g. diodes, peripherals, } \\
\text { computers) }\end{array}$ & $\begin{array}{l}\text { Exports of electronics to world markets } \\
\text { raises ratio of trade to total world output }\end{array}$ \\
\hline \multirow[t]{3}{*}{$\begin{array}{l}\text { Communications technology } \\
\text { (telecommunications and computers) }\end{array}$} & $\begin{array}{l}\text { (a) Information technology promotes global } \\
\text { dispersion of production by multinationals }\end{array}$ \\
\hline & $\begin{array}{l}\text { (b) Information technology promotes global } \\
\text { dispersion of services by multinationals (e.g. } \\
\text { data-processing). }\end{array}$ \\
\hline & $\begin{array}{l}\text { (c) Information technology promotes global } \\
\text { dispersion of } R \& D \text { by multinationals }\end{array}$ \\
\hline Information technology in general & $\begin{array}{l}\text { International strategic alliances in informa- } \\
\text { ion technology promote globalization }\end{array}$ \\
\hline
\end{tabular}

Source: based on James (1999).

corporations to disperse their global production activities to a much greater extent than was previously feasible; what emerges as a result is a correspondingly greater number of export platforms that are linked together in an integrated manner across a variety of different countries. Those developing countries that are able to form part of such systems thus benefit not only from the globalizing influence exerted by the foreign direct investment itself, but also from the exports that are subsequently generated.

To the extent that cumulative patterns of this kind inhere in the global economy, the technological modes of global integration described in Table 1 will exert a pro-rich bias that is even greater than the sum of the individual mechanisms. From the standpoint of global equity, the need for a pro-poor policy agenda consequently becomes all the more pressing.

\section{PRO-POOR MODES OF TECHNICAL INTEGRATION INTO THE GLOBAL ECONOMY}

The question that now needs to be addressed is how the poorer members of developing countries (whose characteristics were broadly described above), can become better integrated into the global economy by means of the 
mechanisms listed in Table 1. First, however, it is important to recognize that not all the mechanisms are equally suitable for this purpose. It is difficult, for example, to see how the poor could benefit from structural alliances entered into by the largest firms in the East Asian NICs, which are the major participants from countries outside the Triad region formed by the United States, Western Europe and Japan (see Vonortas and Safioleas, 1997). It is just as difficult to imagine how those living in poverty could benefit (in any direct fashion) from the location in their particular countries of $R \& D$ facilities by multinational corporations, especially since such $R \& D$ tends to generate 'global' innovations that can be used throughout the corporation as opposed to the more familiar type of innovations that are adapted to the particular conditions prevailing in the developing country concerned.

Of the remaining mechanisms listed in Table 1, however, there are a number that seem to afford opportunities for the poor to be more closely integrated into the global economy. Following the order of the discussion in the previous section, let us begin with the mechanisms that deal with international trade.

\section{Trade-induced Mechanisms}

We have already acknowledged the fact that most of the poor in developing countries live in rural rather than urban areas. We have also seen that tradeinduced integration into the global economy via information technology is closely associated with removing or lessening information imperfections of one kind or another. To these two points we can add the recognition that rural areas in developing countries are generally much less well served by telecommunications facilities than urban areas. According to Kayani and Dymond:

A decade of Maitland awareness has actually achieved very little toward alleviating the disparities between urban and rural communities. The average imbalance, in terms of telephone penetration, in Asia, for example, is over 10 to 1 and is often as high as 20 to 1 . This means that a country whose urban markets have a penetration of, say, 4 telephone lines per 100 inhabitants (e.g. India and Pakistan) has a rural penetration of less than 0.2 per 100 . The situation is more acute in most African countries and in some parts of Latin America. (Kayani and Dymond, 1997: 2)

We can conclude that the rural poor will not be able to participate more fully in the international trading system without some means of communication with the various actors that form part of this system. From the standpoint of this article, one is led, in policy terms, to ask whether and to what extent information technologies are capable of redressing the problem. In other words, what role is there for such technologies in rural telecommunications that seek to promote the closer integration of low-income groups into the global trading system? 


\section{Information Technology and Rural Telecommunications}

It is often argued that in the area of telecommunications, developments in information technology enable developing countries to bypass the older and relatively expensive technology that already exists in the developed countries and to proceed directly (or 'leapfrog') to the more modern electronic (or digital) systems. In the specific context of the rural sector, Kayani and Dymond claim that:

technological advances provide opportunities for developing and transitional economies to accelerate ... telecommunications development and thereby avoid waiting decades, even generations, to increase rural teledensity to some minimal standard of access.

The current proliferation of technical options from which to choose, particularly radio-based systems, is illustrative of the speed at which technology is changing ... even low-income countries now have opportunities to enhance rural teledensity beyond what had been previously feasible. (ibid.: 8)

As far as the dispersed groups of rural poor are concerned, however, what is required is not digital telecommunications equipment per se, but rather small-scale rural exchange systems that embody this technology. Whereas in the United States and Europe even the smallest exchanges accommodate between 4,000 and 10,000 lines, what is required in the hundreds of thousands of villages that exist in large developing countries such as India, are telephone exchanges that accommodate only 100 to 200 lines. Indeed, it was precisely on the basis of this recognition that a pro-poor group of engineers in India set out in the 1980s to design a small-scale telephone exchange for village use. By 1987, a 128-line digital exchange system had been built, which was appropriate not only in terms of its size but in other important respects as well:

even digital switching produces heat, so switching equipment has to be airconditioned in order to function dependably. But in the countryside, the Indian electrical grid is notoriously undependable ... The solution was simple but ingenious. First, to produce less heat, we used low-power microprocessors and other devices that made the exchanges work just slightly slower. Second, we spread out the circuitry to give it a little more opportunity to "breathe". $\ldots$ The final product was a metal container about three feet by two feet, costing about $\$ 8,000$, that required no air-conditioning and could be installed in a protected space somewhere in the village and switch phone calls more or less indefinititely in the heat and dust of an Indian summer as well as through the torrential Indian monsoon. (Pitroda, 1993: 74)

Even in cases such as these, however, where every effort is made to exploit the potential of information technology for the benefit of the rural poor in developing countries, it is simply not realistic to provide telephone lines to each and every household. The problem, of course, lies on the demand side and has to do, in particular, with the income levels of the poorer members of the rural population (low population density is also a problem, especially, but not only in sub-Saharan Africa). 'From a policy perspective', therefore, 'the advanced country universal service delegation, to serve all potential 
demand, yields to the much more modest universal access obligation, to bring the network within reach of the populace through points-of-presence at the community level' (Kayani and Dymond, 1997: 7).

Universal access to telephones in rural villages can be sought not only via the increased use of strategically-located coin-operated telephones, but also through the more recently conceived device of franchising the service to private entrepreneurs in the form of so-called 'phone shops'. This latter approach has been used to particularly good effect in India and Bangladesh, where basic telephony has become increasingly available to the vast numbers of rural poor in those countries.

\section{Phoneshops}

Bangladesh suffers to a greater extent than most other developing countries from a lack of conventional telecommunications infrastructure. ${ }^{5}$ In 1996 Grameen Telecommunications, a branch of the well-known Grameen Bank, was founded in order to redress this acute lack of basic telephony, by providing cellular mobile phone services to no fewer than 100 million occupants of 68,000 Bangladeshi villages over a four year period. 'This initiative', according to the company, 'will provide modern telecommunications services to millions of the poorest people of the world'. ${ }^{6}$ For this purpose Grameen Telecom makes use of a digital cellular radio phone system which is able to 'provide telephony where wire or fiber infrastructure is not available. The flat terrain of the country is conducive to good wireless communications' (Dumas, 1999: 7). The technology makes use of renewable solar energy to recharge the phones, and in this sense as well, can be considered appropriate to the local environmental circumstances.

If Grameen Telecom can thus be said to exploit recent advances in the field of rural telecommunications, it is also true that it draws on the wellestablished principles of the Grameen Bank to provide widespread rural access to these new technologies. Just as the original strategy of the Bank was to provide poor villagers with 'micro credit loans' to establish small businesses, the goal of the Grameen Telecom project is to make loans available to women recruited from among the Bank's borrowers, who, after purchasing a cellular phone on credit, make the service available at a certain price to an entire village. In 1996, its inaugural year, Grameen Telecom recruited 250 rural women for the cellular phone project, but the ultimate goal of the company is to provide the necessary financing for 60,000 members of the Grameen Bank. In this way, the Grameen rural telecommunications

5. According to one recent estimate, for example, there are only two phones per 1,000 inhabitants of the country; see Dumas (1999).

6. Grameen Telecom web site: www.grameen-info.org. 
project helps to alleviate poverty in Bangladesh not only by providing the poor with better access to the information on which much trade in goods and services crucially depends, but also because the low-income women borrowers involved in the project use the micro-financed cellular phones as a means of household income generation. ${ }^{7}$

In the somewhat similar case of India, we have already seen how smallscale digital exchanges were designed explicitly for local environmental conditions. 'What ... remained was to disseminate this new technology through the Indian telecommunications system and actually reach out to the towns and villages that needed it' (Pitroda, 1993: 74). 'In most areas, coinoperated phones seemed a poor idea for any number of reasons, including the fact that they cost a great deal to manufacture' (ibid.: 76). What was chosen instead was a 'phoneshop' model similar in its essentials to the Grameen Telecom case. Telephones equipped with small meters were 'put into the hands of entrepreneurs who set them up on tables in bazaars, on street corners, or in cafes or shops whose owners feel they attract customers. These telephone "owners", frequently the handicapped, take in cash from their customers but are billed only six times a year, with 20 to 25 per cent discounted as their commission. The phones are in such constant use that, in most cases, the revenue is enough to support a family' (ibid.: 78). Again, as in the Bangladesh case, the apparent success of this 'phoneshop' initiative derives partly from the fact that each owner/operator has a 'built-in' incentive to diffuse the service as widely as possible, to ensure that the prices of telephone calls are affordable even by those with low incomes and to keep their lines in good working order.

\section{Telecentres}

A logical extension of the phoneshop concept is often referred to as a 'telecentre', to denote a privately operated venture where the customer can not only make telephone calls, but also has access to the new communications technologies such as fax machines, e-mail and so on. Thus, telecentres can be broadly defined as 'multi-purpose centres aimed at providing computers and telecom facilities and support for local communities in remote, rural regions and in low-income urban settlements.... Hardware and telecom services vary between centres, but typically include a photocopy machine, personal computers and printers, access to ordinary telephone network or ISDN, modems for data communication (databases, electronic mail, etc.) and a telefax machine' (Qvortrup, 1994: 1-2).

7. According to one estimate, the average income per village telephone operator was in excess of $\$ 700$ per annum (Ernberg, 1998). For a detailed empirical study of the extent to which the poor gain from the Grameen telecommunications project, see Bayes et al. (1999). 
Unfortunately, the transition from phoneshops to telecentres involves far more than simply adding additional (and more complex) facilities to an already functioning system that revolves around a single owner/operator. Unless the user capabilities of the target groups of beneficiaries rise concomitantly, these more complex technological facilities will simply remain unused or underutilized (even assuming that problems of electricity and telecommunications can be overcome). According to Fuchs (1998: 3):

Telecentres are about much more than the Internet. Telecentres are the locus for the diffusion of skills and access to tools associated with the Information Society. Simple access to the Internet assures only that those who already know how to use the computing and telecommunications devices and know the value of information will have access to an individual resource. Telecentres help bring many more people to this point of personal information capacity. Telecentres are not the Internet. They are about a much broader diffusion of skills and tools for the Information Society. (emphasis added)

This lesson had already been learnt from the early experience with telecentres that were established in remote rural areas of developed countries such as Sweden, Australia and Canada. In rural areas of many contemporary developing countries, where the disparity between existing and required user capability is all the more marked, the problems of establishing successful telecentres may be correspondingly more pronounced. From the numerous pilot telecentre projects that are currently being implemented in many parts of the Third World, certain problems are already emerging. Fuchs, for example, points to a 'special challenge for the successful growth of telecentres in sub-Saharan Africa', by which he means:

The general society and culture within which telecentre managers and staff will be working will have very little initial experience with or understanding of information and network technologies. They will, thereby, have even fewer local resources to rely upon for crosstraining and support than was the case in the first wave of telecentres in Europe, Canada and Australia. The importance, thereby, of ensuring that telecentre staff and managers in Africa have a forum within which to meet becomes even more paramount. (ibid.: 3 )

Another problem which is emerging is the fact that 'There is as yet little relevant information and knowledge available electronically in a language and format rural people in developing countries can understand and use. Relevant "content" needs to be developed and adapted to user-friendly interfaces' (Ernberg, 1998: 17).

Whether and to what extent these and other problems of building indigenous user capabilities among the rural poor can be overcome, will become clearer as more experience is gained from the ongoing telecentre pilot projects. ${ }^{8}$ Although these projects are being undertaken by a large

8. See, for example, the review of the South African experience with pilot telecentre projects by Khumfalo (1998). 
number of different institutions, ${ }^{9}$ the subsequent learning effects will be greatest if the results are drawn from a large sample that is not bound by institutional divisions of any kind.

\section{Electronic Commerce}

One of the activities that might be expected to emerge from fully-blown telecentres in the future is electronic commerce, that is, the buying and selling of goods and services on the Internet. Certain pilot telecentre projects already direct their training policies towards precisely this objective. It is unnecessary to wait for such institutions to emerge, however, since there are other methods by which low-income groups in developing countries can be helped to benefit from this rapidly growing form of trade. In fact, such propoor forms of electronic commerce are already taking place, to a limited extent, on the basis of methods that have been pioneered by an NGO based in the United States known as 'PEOPLink'.

Generally speaking, the low-income producers that PEOPLink are most concerned to assist are rural artisans, the vast majority of whom are women. These artisans traditionally have to rely on a long chain of intermediaries before getting their products to world markets and as a result are usually deprived of a sizeable share of the ultimate profits. As an alternative, PEOPLink advocates the use of various types of information technology that enable artisans to market their products directly on the Internet, thereby eliminating the middlemen and raising the proportion of the profit that accrues to the producers themselves. A crucial role in this alternative process is played by a network of 'trading partners' in developing countries, who are 'usually nonprofit organizations that provide marketing and design services to numerous producer groups. Often the TPs [trading partners] also have other community development activities such as health or education programs'. ${ }^{10}$ PEOPLink provides its trading partners with information technologies of various kinds and ensures that the user capabilities associated with these technologies are acquired. The trading partners, in turn, work with and assist the rural artisans, teaching them, for example, how to photograph their products with the aid of digital cameras and forwarding the results to the headquarters of the NGO in the United States, where they are posted on the Internet (at a site which includes, among other items, alpaca clothing from Bolivia, sweaters from Guatemala, iron sculptures from Haiti and handwoven baskets made by a group of women in Uganda to support children orphaned by AIDS).

\footnotetext{
9. Among the most important of which are the ITU (the International Telecommunications Union) and the IDRC (the International Development Research Centre in Canada). See the list of institutions at the FAO web site: www.fao.org.

10. See the PEOPLink web site: www.peoplink.org.
} 


\section{Foreign-investment Induced Mechanisms}

We saw in Table 1 that information technology enables multinational corporations to engage in a more dispersed location of their economic activities - not only the production of goods and services, but also expenditures on R\&D. By itself, this does not tell us whether and how developing countries are likely to be affected (nor, by extension, does it give much away about the probable effects on different income groups within those countries). In order to begin addressing these questions, a further factor must be recognized, namely that information technologies (in conjunction with various forms of policy liberalization in both developed and developing countries) have also made the international economy more competitive. To this extent, not only has it become technologically more feasible for multinational firms to engage in a dispersed pattern of locational behaviour, but it has also become more necessary for them to do so.

In many cases (as suggested earlier) the integrated production strategies of these firms will favour highly skilled workers in the more developed parts of the Third World (as when, for example, R\&D centres are established in the East Asian countries; see UNCTAD, 1995). In other cases, however, the globally integrated systems of foreign investment can be made to benefit low-income groups in the poorest regions of the developing world. What is common to these pro-poor forms of global integration is an increased demand for unskilled, often female labour, which, as noted above, often forms an important component of the poverty profile in many developing countries. These mechanisms, in turn, revolve to a large degree on the role of labour-intensive methods of production in the emerging international division of labour. ${ }^{11}$

\section{Labour-intensive Methods of Production in Globally-integrated Systems of Foreign Investment}

As a method of production (in the form, say, of CAD or NCMTs), information technology would dominate (and hence tend to eliminate) existing methods of production, if it was more efficient than the latter, at all factor price ratios, including those where the price of labour is low relative to the price of capital (as is generally the case in developing countries). In that event, techniques based on information technology could produce the same amount of output with fewer inputs than all competing methods of production (or, more formally, with less of one input and no more of the

11. Note that we are not addressing the wider question of whether an export-led pattern of industrialization would benefit the poor more than a more locally oriented one. This lies outside our purview and would require a separate paper to discuss. 
other). The available evidence, however, suggests that this is not the case. ${ }^{12}$ While there are circumstances in which information technologies are more profitable than other, more labour-intensive alternatives, there are also situations (especially in developing countries) where this is plainly not so. In some sectors (such as clothing and textiles) there are countries in which the prevailing factor prices are such that even unskilled-labour intensive methods of production are more efficient than the techniques based on information technologies (Mody and Wheeler, 1990; see also Hoffman and Rush, 1988). It is well known that much of the foreign direct investment undertaken in the 1960s was designed to exploit cost advantages of this kind (see, for example, Henderson, 1989). What is less well known, however, is that this type of foreign investment 'began to flourish only under conditions of globalization' (UNCTAD, 1998: 108, emphasis added). Paradoxical as this statement may at first appear, it can readily be resolved by the arguments provided in the 1998 World Investment Report:

In a world with trade barriers, limits on the movements of factors of production and overwhelmingly non-tradable services, TNCS pursued differentiated strategies based on stand-alone foreign affiliates, relatively independent from parent companies and without links to other affiliates of the same parent firm. Thus they were mostly horizontally organized enterprises with plants in a number of countries. Vertically integrated structures were limited to natural-resource TNCs. Only under conditions of globalization did TNC strategies give rise to vertically integrated TNC structures, also in other sectors, spread across the globe. (UNCTAD, 1998: 109)

In other words, vertically integrated production strategies:

only began to prosper when barriers to trade and FDI were lowered; costs and time needed to transport goods over long distances were reduced and communication technology permitted not only the overall coordination and management of affiliates located even in different continents, but also the immediate adjustments of design or product specifications in response to demand changes. (ibid.: 110)

The vertical type of integration of foreign investment thus being engendered by globalization has taken the form, initially, of so-called 'simple integration strategies', which:

aim at reducing the production costs of labour-intensive products or processes in the valueadded chain. They entail the transfer of these products or processes to foreign affiliates, controlled through equity or non-equity arrangements (e.g. subcontracting), established in countries that offer the locational advantages required by these processes ... The principal locational advantage needed to guide FDI guided by this strategy is unskilled labour. [However] ... As more countries compete for this type of investment, they offer locational advantages that go beyond low-cost labour. (ibid.: 110, emphasis added)

The last phrase above bears especially heavily on the question of devising policy that will enable the poorest parts of the developing world to share in the benefits of simple integration strategies pursued by foreign-owned firms.

12. The most detailed evidence on this point is provided by Mody and Wheeler (1990). 
For although the relative abundance of unskilled labour in those regions may in itself be attractive to such firms, it is also precisely in the poorest developing countries that the other relevant factors (such as an adequate infrastructural environment) are often most lacking.

Nowhere is this problem clearer than in countries belonging to the subSaharan region, which, in spite of having an unskilled labour supply that seems abundant even by Third World standards, have attracted little or no foreign direct investment in manufacturing industry. These countries lack, among other things, an adequate industrial infrastructure, a policy of active and consistent investment promotion, and low unit labour costs (as distinct simply from low nominal wages). Yet, in the few exceptions that do exist to the typical African case, we see just how potent a source of poverty alleviation foreign investment can be, when it is aimed primarily at exploiting the cost advantages offered by cheap unskilled labour. In Mauritius, for example, the use of export processing zones and the granting of various types of incentives to multinationals, produced such a sharp increase in (mainly textile) exports, that unemployment, 'once the most pressing problem' on the island (German Development Institute, 1992: 44), has been eradicated. No less striking is the experience in Lesotho, whose exports of light, labourintensive products (mainly clothing and footwear) increased from a value of US\$ 6 million in 1985 to US\$ 123 million in 1994 (World Bank, 1998). In both countries, much of this remarkable growth in manufactured exports can be attributed to the presence of multinational corporations, and what seems to have attracted those firms was not merely the availability of cheap unskilled labour, but a number of other factors as well, such as preferential access to major Western markets, and the availability of an adequate industrial infrastructure (ibid.).

From the point of view of the mechanisms listed in Table 1, there is another similarity between these two African countries which bears emphasis in the present context. Both countries were able to attract export-oriented foreign investment not only in traditional manufactures such as textiles and footwear, but also (albeit on a smaller scale) in electronics products themselves. In so doing, these countries thus exploited an additional mechanism through which global integration based on foreign investment can be used to increase the demand for unskilled local labourers, many of whom might otherwise have remained unemployed (the additional mechanism is listed in Table 1 as 'exports of electronic products to world markets').

\section{Services}

So far we have confined our discussion of how simple integration strategies are being undertaken by multinational corporations to goods such as textiles and clothing, which are typically produced most efficiently when the wages of unskilled labour are low relative to the price of capital. As noted earlier, 
however, advances in information technologies have enabled certain service activities that were formerly carried out within the firm to be performed in other countries. Simple data-entry operations, for example, were one of the first information technology-based activities to be 'globally outsourced' because they require minimal levels of computer literacy and 'very little interaction between the customer and the vendor' (Apte and Mason, 1995: 1252). In this sector, no less than in more traditional tradables, 'Global competition, spurred by liberalization of trade in goods, has led firms to seek new means of improving competitiveness, including shifting of noncritical services from in-house units to outside service providers' (World Bank, nd: 2).

It is true that this global dispersal of data-processing and other service activities appears, thus far, to have favoured a group of relatively affluent developing countries, especially those in the East Caribbean region. ${ }^{13}$ It is equally true, however, that within those countries, the activities of foreignowned firms have created large numbers of jobs for unskilled, female workers. Furthermore, 'In spite of the precariousness of employment contracts and low basic wage rates, total remuneration for offshore data-entry clerks often compares well with earnings in other local employment (this was found to be the case in Jamaica, for instance, vis-à-vis manufacturing employment)' (Pearson and Mitter, 1993: 60). On a smaller scale, simple data-processing activities are also known to occur in much poorer countries such as China and India, where the contribution to the more severe type of poverty described earlier is likely to be greater. ${ }^{14}$

\section{CONCLUSIONS}

In spite of widespread agreement that the benefits of globalization induced by information technology tend to be skewed in favour of a relatively small group of developing countries (mainly but not exclusively in East Asia), one can also find examples where this same technology appears to have had the opposite effect, of integrating the poorer rather than the more affluent inhabitants of the Third World into the global economy. At present, however, these counter examples are highly fragmented not only in terms of the regions and forms of information technology that they involve, but also in terms of the particular poverty groups to whom the benefits are thought to accrue.

The purpose of this article, accordingly, has been to suggest a more systematic framework with which to assess the pro-poor potential of

13. By 1993, for example, Barbados and Jamaica were jointly employing about 5,000 workers in offshore data entry and processing (James, 1999).

14. Much, of course, depends on whether the alternative for those employed in export processing zones is unemployment. 
globalization that is based on various forms of information technology. With this in mind, we looked at the various modes of integration through which individuals and firms can potentially be integrated by information technology into the global systems of trade and foreign investment. With respect to each such mechanism, we described the conditions under which the various categories of the poor can be more intensively integrated into and benefit from the newly emerging global economy. With the partial exception of village 'phoneshops', some of which have emerged spontaneously as a result of local entrepreneurship, examples of pro-poor modes of global technical integration have largely been introduced by non-market actors, such as NGOs, governments and international organizations.

NGOs can play an important role in stimulating pro-poor modes of technical integration as illustrated by at least two of the examples presented here, namely, the connection of rural artisans to the Internet and the supply of cellular phones to villages in Bangladesh. The role that governments and donors can play in this process, however, needs to be spelled out somewhat more explicitly. In the case of the former, emphasis should be placed above all on policy-making with respect to rural telecommunications - not only because it is mainly the rural poor that suffer most from a lack of information, but also because it is basic telephony on which other, more sophisticated forms of information technology crucially depend. Since telecommunications services in developing countries have traditionally been provided by state-owned monopolies that have generally failed to make much progress in meeting the demand for such services in rural areas, policy reform of one kind or another will be required. The increase in rural payphones in Bangladesh referred to above, for example, was due in part to government efforts to encourage more competition in the cell-phone market, which led to the granting of a licence to the Grameen Bank, as well as other operators. In contrast, Senegal is widely cited as an example of how privatization alone can stimulate the growth of payphones in a poor country that was formerly served by a monopoly supplier of basic telephony. ${ }^{15}$ In many other countries, however, the response to privatization is likely to be less spectacular and a subsidy will be required for the establishment of rural payphones; the problem for governments will be in deciding how high this should be. Subsidy auctions, as practised with some degree of success in Chile, may turn out to be useful. The government there awarded subsidies on a competitive basis to firms providing telephone services to small and remote localities, with firms bidding against each other for the right to perform such a service.

Aid donors can assist governments with these reform efforts in a number of different ways, such as the provision of advice or the mobilization of

15. Between 1993 and 1997, for instance, the number of private payphones in Senegal increased from 1,221 to almost 7,000 
finance (in the form of investments, loans and grants). ${ }^{16}$ Donors can also help with the sponsorship of pro-poor information technology projects that embody 'high pay off potential and equally high risk' (Talero and Gaudette, 1996: 7). Perhaps most promising from this point of view are community information centres, since: 'This multi sectoral concept can provide residents, nongovernmental organizations, and business in poor rural and urban areas with economical, easy, and ready access to needed information. The centres could be a powerful engine of rural development and a preferred instrument in the fight against poverty' (ibid.: 7).

Finally, a related role for aid donors (as well as, and perhaps in conjunction with, NGOs and governments) concerns the financing of, and the dissemination of information about, appropriate telecommunications technologies. As noted above in connection with the small-scale rural telephone exchanges in India, such technologies - emanating as they generally do from the industrialized Western societies - are rarely suited to the socioeconomic conditions prevailing in poor, sparsely populated developing countries. If the poor in those latter countries are to be more closely integrated into and to benefit from the global economy, considerable effort will be required to develop technologies specifically designed for this purpose.

\section{REFERENCES}

Apte, U. and R. Mason (1995) 'Global Disaggregation of Information-intensive Services', Management Science 41(7): 1250-62.

Bayes, A., J. von Braun and R. Akhter (1999) 'Village Pay Phones and Poverty Reduction: Insights from a Grameen Bank Initiative in Bangladesh'. Discussion Paper on Development Policy No 8. Bonn: Center for Development Research.

Dumas, J. (1999) 'The Grameen Bank: Development from the Bank of Beggars to Telecommunication Provider', Pacific Telecommunications Review 20(3): 5-15.

Dunning, J. and R. Narula (1996) 'Developing Countries versus Multinationals in a Globalising World: The Dangers of Falling Behind'. Research Memo 2/96-022. Maastricht: MERIT.

Ernberg, J. (1998) 'Universal Access for Rural Development: From Action to Strategies'. Paper presented at the First International Conference on Rural Telecommunications, International Telecommunications Union, Washington (30 November-2 December).

Freeman, C. and J. Hagedoorn (1995) 'Convergence and Divergence in the Internationalization of Technology', in J. Hagedoorn (ed.) Technical Change and the World Economy, pp. 34-57. Aldershot: Elgar.

Fuchs, R. (1998) 'Little Engines that Did: Case Histories, from the Global Telecentre Movement'. Ottawa: International Development Research Centre (mimeo).

German Development Institute (1992) 'Perspectives of the Clothing and Textile Industry in Mauritius in the Face of Changing External and Internal Conditions - Challenges for Enterprises and Institutions'. GDI Working Paper. Berlin: German Development Institute.

Griffin, K. and J. James (1981) The Transition to Egalitarian Development. London and Basingstoke: Macmillan.

16. For a full discussion of the possible role for the World Bank, see Talero and Gaudette (1996). 
Henderson, J. (1989) The Globalisation of High Technology Production. London and New York: Routledge.

Hoffman, K. and H. Rush (1988) Micro-Electronics and Clothing. New York: Praeger.

James, J. (1998) 'Information Technology, Globalization and Marginalization', in A. Bhalla (ed.) Globalization, Growth and Marginalization, pp. 48-69. London and Basingstoke: Macmillan.

James, J. (1999) Globalization, Information Technology and Development. London and Basingstoke: Macmillan.

Kayani, R. and A. Dymond (1997) 'Options for Rural Telecommunications Development', World Bank Technical Paper No 359. Washington, DC: The World Bank.

Khumfalo, F. (1998) 'Primary Evaluation of Telecentre Pilot Projects', prepared for the International Telecommunications Union. South Africa: Universal Service Agency (mimeo).

Mody, A. and D. Wheeler (1990) Automation and World Competition. London and Basingstoke: Macmillan.

Myrdal, G. (1957) Economic Theory and Under-Developed Regions. London: Duckworth.

Pearson, R. and S. Mitter (1993) 'Employment and Working Conditions of Low-Skilled Information-Processing Workers in Less-Developed Countries', International Labour Review 132(1): 49-64.

Pitroda, S. (1993) 'Development, Democracy and the Village Telephone', Harvard Business Review 71(6): 66-79.

Qvortrup, L. (1994) 'Community Teleservice Centres: A Means to Social, Cultural and Economic Development of Rural Communities and Low-Income Urban Settlements'. Paper presented at World Telecommications Development Conference, Buenos Aires (21-29 March).

Talero, E. and P. Gaudette (1996) 'Harnessing Information for Development'. Washington, DC: The World Bank (mimeo).

UNCTAD (1995) World Investment Report. New York and Geneva: UNCTAD.

UNCTAD (1996) World Investment Report. New York and Geneva: UNCTAD.

UNCTAD (1998) World Investment Report. New York and Geneva: UNCTAD.

UNDP (1999) Human Development Report. New York: Oxford University Press.

Vonortes, N. and S. Safioleas (1997) 'Strategic Alliances in Information Technology and Developing Country Firms: Recent Evidence', World Development 25(5): 657-80.

World Bank (1995) World Development Report. New York: Oxford University Press.

World Bank (1996) Global Economic Prospects for Developing Countries. Washington, DC: The World Bank.

World Bank (1998) 'Lesotho's Garment Exports: Attracting Foreign Direct Investment'. Africa Region, No 103 (Jan.). Washington, DC: The World Bank.

World Bank (n.d.) 'Prospects for Service Exports from the English-speaking Caribbean'. Report prepared by the Public Sector Modernization and Private Sector Development Division. Washington, DC: The World Bank.

Jeffrey James is Professor of Development Economics at CENTER and the Department of Economics, Tilburg University, P.O. Box 90153, 5000 LE Tilburg, The Netherlands. He is also currently interim Director of Graduate Studies in Economics and Management at that university. 